\title{
Teaching Grammar in Context: Why and How?
}

\author{
Çağrı Tuğrul Mart \\ Department of Langauges, Ishik University, Erbil, Iraq
}

\begin{abstract}
Grammar instruction is one of the most difficult issues of language teaching. Context-based grammar holds an important place for effective learning. It will be more motivating for learners if grammar is taught in context as students will have an opportunity to perceive how the new grammar structures work. Grammar rules are made easier if they are given in a context and teaching grammar in context provides accuracy in the target language. This article explains why we should teach grammar in context and presents two sample lessons.
\end{abstract}

Index Terms - teaching grammar, context, accuracy, communication

\section{INTRODUCTION}

Grammar is rules of a language. "Grammar is a system of meaningful structures and patterns that are governed by particular pragmatic constraints" (Larsen-Freeman, 2001). In another definition "grammar is a description of the rules for forming sentences, including an account of the meanings that these forms convey" (Thornbury, 1999, p.13).

In foreign language acquisition accurate understanding of the language structures is the key part so teaching grammar is an essential aspect of foreign language instruction. There has always been a debate about the most effective way of teaching grammar. Grammar instruction through context positively affects learners' competence to use grammatical structures accurately in language skills. It is always useful for learners to see how language works in sentences or paragraphs; therefore, teaching grammar in context will give learners opportunities to see how grammatical structures function in sentences. Teaching grammar in context will help learners to acquire nature of the language which will facilitate their understanding of the language.

\section{Why We ShOULD TeACH GRAMmaR}

Grammar instruction should not be ignored. About grammar teaching, Krahnke (1985, p.598) suggests that "much of the effort spent arguing against the teaching of grammar might be better spent on convincing true believers in grammar instruction that grammar has a newly defined but useful role to play in language teaching and in showing them what it is" (Terrell, 1991, p.54). For a better language improvement, grammar plays a crucial role.

To be an effective language user, learners should study grammar because grammar skills will help learners to organize words and messages and make them meaningful. Knowing more about grammar will enable learners to build better sentences in speaking and writing performances. A good knowledge of grammar helps learners to make sentences clear enough to understand. Improper use of grammar will not convey meaningful messages. Tabbert stresses the importance of grammar simply as: "It is frequently pointed out that students confuse lie and lay, do not choose who and whom correctly, say infer instead of imply, mismatch subjects and verbs, mix up pronoun reference, use double negatives, etc., and that these mistakes are evidence of their need to study grammar" (Tabbert, 1984, p.39).

To establish an effective communication, learners need grammar skills; therefore, without grammar, speech gets meaningless. Grammar is an essential aspect to communicate effectively. Moreover, grammar simply is creating wellorganized reading and writing performances. John Warriner supporting this idea (n.d., p. 8) writes: "The chief usefulness of grammar is that it provides a convenient and, indeed, as English is taught today, an almost indispensable set of terms to use in talking about Language (Tabbert, 1984, p. 40)."

Grammar will give learners the competence how to combine words to form sentences. To create fully-developed sentences, grammar knowledge is indispensable. With little understanding of how language functions, learners cannot develop their language skills. "Just as there are careful and effective drivers who do not know what makes a car run, so there are those who, through practice and skillful observation, have become satisfactory, even effective, writers with very little understanding of the mechanics of the language. But it follows that the more you know about the form and function of the parts that make up the larger unit, the sentence, the better equipped you are to recognize and to construct well-formed sentences...." (Emery, et al, 1978, p. 1)

Grammar instruction holds an important place in foreign language learning. It needs to be noted that grammar skills will make great contribution to language competence. "The study of the structure and history of language, including English grammar, is a valuable asset to a liberal education and an important part of the English program. It should, however, be taught for its own sake, not as a substitute for composition, and not with the pretense that it is taught only to improve writing" (NCTE Commission on Composition, 1974, no. 12). 
Teaching grammar is to show how language works. Accurate teaching of grammar guides learners how to use the language correctly. Azar highlights the significance of teaching grammar as: "One important aspect of grammar teaching is that it helps learners discover the nature of language, i.e., that language consists of predictable patterns that make what we say, read, hear and write intelligible. Without grammar, we would have only individual words or sounds, pictures, and body expressions to communicate meaning. Grammar is the weaving that creates the fabric" (Azar, 2007). To establish precise sentences, grammar knowledge is essential. In another idea about why teaching grammar is important Ellis writes: "Grammar Teaching involves any instructional technique that draws learners' attention to some specific grammatical form in such a way that it helps them either to understand it metalinguistically and / or process it in comprehension and / or production so that they can internalize it" (Ellis, 2006, p.84).

Language acquisition without grammar will be confusing. Learners will fail to use the language correctly without grammar skills. "People now agree that grammar is too important to be ignored, and that without a good knowledge of grammar, learners' language development will be severely constrained" (Richards, Renandya, 2002, p.145). Richards and Renandya point out two good reasons for teaching grammar (2002, p.152):

a) Comprehensibility:

Knowing how to build and use certain structures makes it possible to communicate common types of meaning successfully. Without these structures, it is difficult to make comprehensible sentences. We must, therefore, try to identify these structures and teach them well.

b) Acceptability: in some social contexts, serious deviance from native-speaker norms can hinder integration and excite prejudice- a person who speaks 'badly' may not be taken seriously, or may be considered uneducated or stupid. Students may therefore want or need a higher level of grammatical correctness than is required for mere comprehensibility.

Teaching grammar will help learners to understand the nature of language. Azar notes down the benefits of grammar teaching as: "One of the principal benefits of GBT (Grammar-Based Teaching) is that it helps students gain an understanding of grammar concepts: concepts such as subordination and coordination; concepts of expressing time relationships through the use of verb forms; concepts of nouns and adjectives, subjects and verbs, clauses and phrases. Students can understand grammar concepts with simplified terminology, with a minimum of metalanguage and grammatical analysis, and even without definition of key terms such as noun or verb" (Azar, 2007). With a good knowledge of grammar, the relationship between grammatical concepts gets clear. Being aware of this relationship facilitates understanding the language.

Grammar skills will enable learners to be aware of parts of a language such as verbs, and nouns. Learners will understand and use the grammatical concepts better if they study grammar. Mulroy states the importance of grammar teaching as: "Sentences always have and always will consist of clauses with subjects and predicates and of words that fall into classes fairly well described as verbs, nouns, adjectives, adverbs, pronouns, prepositions, conjunctions, and interjections. Individuals who understand these concepts have a distinct advantage over others where the use of language is involved - and that means everywhere" (2003, p.118).

Grammar instruction provides learners with a better improvement. Grammar knowledge will increase learners' comprehension of the language. Azar, from her experiences writes that "I observed that students in my writing class who had experienced grammar instruction had an advantage over those students who had not. Students with a good grounding in grammar needed only to be reminded that, for example, they were trying to say "I was really bored" not "I was really boring." Those without that grounding in grammar needed a lot more teaching time in order to understand, just as one example, the difference between -ing and -ed adjectives (Azar, 2007)".

\section{Why We Should Teach GRAmmar IN CONTEXT}

"Across the various languages and subsystems of grammar, perhaps the most widely practiced traditional approach to grammatical instruction has been portrayed as the three Ps- present, practice, produce" (Larsen-Freeman, 2009, p.523). Long and Doughty, criticizing the three Ps model, state that the traditional approach has some disadvantages. "One of the most trenchant criticisms of this approach is that students fail to apply their knowledge of grammar when they are communicating. Students know the grammar- at least, they know the rules explicitly- but they fail to apply them in communication. This problem has been discussed by others as the "non-interface" problem, in that there is no apparent connection between explicit knowledge of the rules and implicit control of the system, and the "learnability problem" following from the observation that grammar is not learned in a linear and atomistic fashion" (Long \& Doughty, 2009, p. 523). In this approach students are unable to use the grammar rules in speech. They do not understand how grammar rules work in a sentence. Learning grammar in context will allow learners to see how rules can be used in sentences. "Language is context-sensitive. This means that, in the absence of context, it is very difficult to recover the intended meaning of a single word or phrase" (Thornbury, 1999, p.69).

"The teacher's chief task when teaching grammar is to show the students what the language means and how it is used; and must also show them what the grammatical form of the new language is and how it is said and written" (Harmer, 1991, p.56). Teaching grammar in context will give learners an opportunity to understand how language works and this will improve their communication skills. "Students need to get an idea of how the new language is used by native speakers and the best way of doing this is to present language in context" (Harmer, 1991, p.57). Accuracy in language 
acquisition plays an important role to understand both speaking and writing performances. "Context gives a more precise understanding of how to use the grammar, and provides accuracy in the studied language both in oral and written skills" (Wajnryb, 1990, p.6).

Presenting grammar in isolated sentences will not allow learners to see how grammatical structures function in sentences. "By dealing with related units of information rather than isolated bits, more efficient processing becomes possible" (McLaughlin, Rossman, McLeod, 1983, p.138). Context-based instruction has always been useful for learners "Students need to learn language in logical contexts, either through authentic discourse-length input or through language learning materials that stimulate authentic input using sentences that follow in logical sequence" (Hadley, 2003, p.152).

Brown explains the advantages of context-based teaching as:

"A single sentence can seldom be fully analyzed without considering its context. We use language in stretches of discourse. We string many sentences together in cohesive units such that sentences bear interrelationships...

Both the production and comprehension of language are a factor in our ability to perceive and process stretches of discourse, to formulate representations of meaning from not just a single sentence, but referents in both previous sentences and following sentences" (Brown, 1980: 189).

In another criticism of teaching grammar through isolated sentences, Nunan writes that "in textbooks, grammar is very often presented out of context. Learners are given isolated sentences, which they are expected to internalize through exercises, involving repetition, manipulation, and grammatical transformation. These exercises are designed to provide learners with formal, declarative mastery, but unless they provide opportunities for learners to explore grammatical structures in context, they make the task of developing procedural skill- being able to use the language for communication- more difficult than it needs to be, because learners are denied the opportunity of seeing the systematic relationships that exist between form, meaning, and use" (Nunan, 1998, p.102). In grammar instruction the goal is not to teach grammar rules but to teach how to apply them in language skills. "What many may not realize is that, with the absence of transformational stage, we are training ELL students to become grammarians who may excel in diagramming and analyzing language but fail to apply this knowledge to communicative use" (Frodesen, 2001; Leki, 1992). "Students need guidance to translate and transfer traditional grammar knowledge to functional use" (Hillocks, 1986). Unless learners know how to apply grammatical concepts in language skills, knowledge of grammar will not be useful.

"We have learned that grammar should not be taught in isolation from content. But then, neither should content be taught without regard to the language involved. A carefully planned integration of language and content however, holds considerable promise" (Swain, Lapkin, 1989, p.153). Weaver stresses that teaching grammar in isolation will not be useful for learners and concluded that (2001, p.18) "teaching traditional grammar in isolation is not a very practical act". Thornbury adds "if learners are going to be able to make sense of grammar, they will need to be exposed to it in its contexts of use, and, at the very least this means in texts" (Thornbury, 1999, p.72).

"Teaching grammar in context provides a meaningful framework that connects to reality in the targeted language" (Anderson, 2005). Nunan stressing the advantage of teaching grammar in context writes: "An approach through which learners can learn how to form structures correctly, and also how to use them to communicate meaning. If learners are not given opportunities to explore grammar in context, it will be difficult for them to see how and why alternative forms exist to express different communicative meanings" (Nunan, 1998, p.103). "Many researchers stress the fact that learners need to experience grammatical conventions in various contexts in order to control and use them correctly" (Anderson, 2005). Context-based teaching will help learners how grammar structures function in context that will give them an opportunity to develop their comprehension of the grammar rules.

Byrd states that when grammar is studied as arising from context, then a variety of forms emerge as essential to the expression of particular meanings in particular discourse contexts (Byrd, 1998). "It's not just that different types of verbs are related to each other but that in particular kinds of discourse the idea of, relationship must be expanded to include the bond among verbs, nouns, adverbs, textual order, and even particular vocabulary" (Byrd, 2005, p.546).

\section{How to Teach GRAmmaR IN CONTEXT}

"In genuine communication beyond the classroom, grammar and context are often so closely related that appropriate grammatical choices can only be made with reference to the context and purpose of the communication" (Nunan, 1998, p.102). "Some advantages of this method are, students are exposed to the target language in an authentic or near authentic setting, they see or hear the target language before having to focus on it" (Riddell, 2003, p.46).

Using dialogues is an effective way of teaching grammar. "The use of dialogues in grammar teaching is useful because the use of dialogues generally matches learners' expectations of how language is used in the real world: people use language primarily to talk to each other" (Thornbury, 1999, p.76).

In the first sample lesson Scott Thornbury uses a scripted dialogue to teach the present simple to beginners: In the lesson the teacher has chosen the following recorded dialogue from a coursebook to use as a vehicle for introducing the present simple with adverbs of frequency (e.g. usually, always) to a group of beginners (1999, p.73).

Joe: What do you do on weekends?

David: well, that depends. During the school year, I usually have to study on Saturdays. 
J: And how about on Sundays?

D: Well, we always have lunch together, you know, the whole family. Then after lunch, I sometimes go to the park and meet my friends.

$\mathrm{J}$ : Oh? What do you do there?

D: We play soccer, take a walk, or just talk. After that, I go out. I usually go to the movies.

J: How often do you go out of the city?

D: About once a month. My uncle has a small farm in the mountains, so I sometimes drive up there.

J: That sounds nice. Do you go alone?

D: No, my mom, my two sisters and some of our friends usually go too.

J: But why do you go?

D: A lot of things: green trees, clean air, and no people.

J: Oh, just like LA!

D: Ha! That's a good joke.

(adapted from How to Teach Grammar, Scott Thornbury)

Thornbury explains the steps as:

In the first step the teacher tells the class that she is going to play them a conversation between two friends. She asks students to close their books and to listen to the first part of the conversation and to answer this question: What are they talking about: last weekend, next weekend, or every weekend? In the second step once she has established that the conversation is about every weekend she asks the students to listen to the whole conversation and to put these words in the order that they hear them: movies, drive, soccer, go out, study, lunch, park, walk. In the third step she asks the students if they can tell her which of the activities in the list David does on Saturdays, on Sundays, and about once a month. In the fourth step the teacher asks learners to listen for the following words and to match them with the words in the list on the board: usually, always, sometimes. For example:

usually study

always have lunch

sometimes go to the park

In the fifth step the teacher asks learners to focus their attention on two or three of these sentences and to tell her exactly what the speaker says. For example:

We always have lunch together

I sometimes go to the park.

In the sixth step the teacher draws the students' attention to the form of the structure, underlining the verbs and explaining that the present simple is used for routine activities. In the seventh step she asks learners to write two or three more sentences about David, using the above sentence pattern, i.e. subject + adverb + verb $+\ldots$

In the eighth step students listen to the conversation again and check their answers to Step 7, and in the final step she invites the students to write four or five original sentences about themselves using the pattern she has highlighted in step 6 (Thornbury, 1999, p.73-74).

"What is important in this exercise is to choose a text with a high frequency of instances of the targeted grammar item. This will help learners notice the new item, and may lead them to work out the rules by induction" (Thornbury, 1999, p.75). Through conversations grammar can be instructed easily and it will facilitate learner's perceiving the rules better. "Communicative teaching and grammar teaching are not mutually exclusive. They fit hand in glove" (Azar, 2006, p.3).

In the second sample lesson David Riddell teaches two English tenses in a context:

Bertrand is French and he lives and works in the north of France. His English is very good because he studies it at school and uses it in his job. A few months ago, he went to San Francisco for the first time to visit some friends he met in France a few years ago. He stayed for a week and in that time Bertrand and his friends had a very busy time - they visited Fisherman's Wharf, rode the cable cars, saw the sea lions by Pier 39, ate in a different restaurant every day, walked up the steep hills, and did lots of shopping in the fantastic department stores. And, of course, they took lots of photographs.

At dinner one evening Bertrand and his friends- Marie, Myrianne and Norbert- were having dinner when the fire alarm sounded, but the waiters didn't seem to be worried, they just carried on working. Everyone around them carried on eating. They thought it was so weird, everyone carrying on with their meals even though the fire alarm was sounding. Bertrand and his friends decided to get out quickly, but just as they went out of the door they saw a sign by the entrance warning customers that there was going to be a fire alarm test that evening and they should ignore it. Bertrand and his friends quietly sat back down again to continue their meal feeling a bit embarrassed (adapted from Teaching English as a Foreign Language, David Riddell).

Riddell explains the steps as:

In the first step the teacher asks the class if anyone has been to/would like to go to San Francisco. If anyone has, they can tell the others about it. If no one has then they can tell you what they imagine San Francisco to be like. Alternatively the teacher shows pictures of San Francisco to get the class talking about it. 
In the second step the teachers tells students that they are going to read about Bertrand who visited San Francisco. They read the text and answer the questions:

Why did Bertrand visit San Francisco?

How many people was he with?

Why did they stop eating?

Did they finish their meal later?

In the third step the teacher highlights the sentence from the text They were having dinner when the alarm sounded.

In the fourth step the teacher asks students to find other examples of the past progressive and the simple past in the text, to underline them and discuss the use of these tenses in pairs or small groups.

In the fifth step the teacher makes the following points.

In this example from the text, we are using two verb forms - the past progressive (continuous), and the past simple. The progressive is were having and the simple is sounded. In the sentence, they started dinner before the fire alarm sounded, and may or may not have continued after. Thus, the simple interrupts the progressive.

In the sixth step the teacher asks the students to write sentences using these two tenses (2003, p.43-44).

Through context learners will see the usage of grammatical patterns better, and the context will help them understand how to use grammar forms and structures. In the following context again two English tenses are presented.

\section{A Special Offer}

Abibus have been producing top-class cars with unbeatable value for 12 years. We have been talking to you our customers a lot recently to find out if there was any way of making our cars even better than before and you told us that our product is as good as it gets. The only way to make Abibus cars even more attractive would be to reduce the price, but that can't be done... or can it? Well, yes it can! From the beginning of next year, for a period of six months, we are cutting the cost of all our Abibus cars by $10 \%$ - yes $10 \%$ ! So from January 1 next year, Abibus cars will be $10 \%$ cheaper, but still top class. We have been doing business with you for 12 years. Now for the next 12 !

(adapted from Teaching English as a Foreign Language, David Riddell)

Using this text, present perfect and perfect progressive tenses are taught. The teacher highlights the perfect sentences in the text and following the steps given above, these two tenses can be presented to learners of English. An advantage of learning grammar in context is learners will see how structures function in sentences and how sentences are related to each other. This text will help learners to identify the differences between these two tenses and learners will have ideas what these tenses mean and how they are used.

\section{CONCLUSION}

Grammar instruction is a difficult issue in language teaching. Teaching grammar through context will help learners perceive the structures of the language effectively. If learners are given grammatical structures in context, they will be able master the language better. Teaching grammar in context will help learners to acquire new grammar structures and forms. Learners will use grammatical conventions more effectively in communication if they learn them in context.

\section{REFERENCES}

[1] Anderson, J. (2005). Mechanically Inclined. Portland, Maine: Stenhouse Publishers.

[2] Azar, B. (2006). Grammar Teaching and Communicative Teaching: A Hybrid That Works. Retrieved September 12, 2012 from <http://www.azargrammar.com/assets/authorsCorners/Transcript-TESOL2008_HybridThatWorks.pdf>

[3] Azar, B. (2007). Grammar-Based Teaching: A Practitioner's Perspective. TESL-EJ. 11(2). 1-12 Retrieved September 12,2012 from 〈http://www.tesl-ej.org/ej42/a1.pdf>

[4] Bradford, Arthur. (1973). Teaching English to Speakers of English. New York: Harcourt

[5] Brown, H.D. (1980). Principles of Language Learning and Teaching. Englewood Cliffs, NJ: Prentice Hall.

[6] Byrd, Patricia. (1998). Grammar from Context. In P. Byrd \& J. Reid (Eds.), Grammar in the Composition Classroom: Essays on Teaching ESL for College-bound Students, 54-68. Boston: Heinle \& Heinle.

[7] Byrd, Patricia. (2005). Instructed Grammar. In Eli Hinkel (ed.), Handbook of Research in Second Language Teaching and Learning, 545-563. New Jersey: Lawrence Erlbaum Associates.

[8] Ellis, Rod. (2006). Current Issues in the Teaching of Grammar: An SLA Perspective. TESOL Quarterly. 40(1): 83-107.

[9] Emery, D., J. Kierzek, and P. Lindblom. (1978). English Fundamentals, 6th ed. New York: Macmillan.

[10] Frodesen, J. (2001). Grammar in Writing. In Marianne Celce-Murcia (Ed.)., Teaching English as a Second or Foreign Language, 233-248, ( $3^{\text {rd }}$ ed.). Boston:Heinle.

[11] Hadley, A.O. (2003). Teaching Language in Context. USA: Heinle \& Heinle.

[12] Harmer, Jeremy. (1991). The Practice of English Language Teaching. London: Longman.

[13] Hartwell, Patrick. (1985). Grammar, Grammars, and the Teaching of Grammar. College English. 47(2): 105-127.

[14] Hillocks, G.J. (1986). Research on Written Composition: New Directions for Teaching. Urbana, IL: National Council of Teachers.

[15] Krahnke, Karl. (1985). Rev. of Stephen Krashen \& Tracy Terrell, The Natural Approach. TESOL Quarterly 19: 591-603.

[16] Larsen-Freeman, D. (2001). Teaching Grammar. In M. Celce-Murcia (ed.), Teaching English as a Second or Foreign Language ( $3^{\text {rd }}$ edn., pp. 251-66). Boston, MA: Thomson/ Heinle.

[17] Larsen-Freeman, D. (2009). Teaching and Testing Grammar. In Long, M.H. \& Catherine, J. Doughty (ed.), The Handbook of Language Teaching (pp. 518-542). Malde, MA: Wiley Blackwell. 
[18] Leki, I. (1992). Understanding ESL Writers: A Guide for Teachers. Portsmouth: Boynton/Cook.

[19] Long, M.H. \& C., J. Doughty (2009). The Handbook of Language Teaching. Malde, MA: Wiley Blackwell.

[20] McLaughlin, B., T. Rossman, B. McLeod. (1983). Second Language Learning: an information-Processing Perspective. Language Learning 33: 135-158.

[21] Mulroy, D. (2003). The war against grammar. Portsmouth, NH: Boynton/Cook.Publishers, Inc.

[22] NCTE Commission on Composition. (1974). "Teaching Composition: A Statement." Urbana, Illinois: NCTE,

[23] Nunan, D. (1998). Teaching Grammar in Context. ELT Journal 52(2): 101-109. Richards, J. \& W. Renandya. (2002). Methodology in language Teaching. USA: Cambridge University Press.

[24] Riddell, D. (2003). Teaching English as a Foreign Language. London: Hodder Education

[25] Swain, M \& S. Lapkin. Canadian Immersion and Adult Second Language Teaching; What's the Connection? The Modern Language Journal 73:150-159.

[26] Tabbert, Russell. (1984). Parsing the Question "Why Teach Grammar". The English Journal. 73(8): 38-42

[27] Terrell, T.D. (1991). The Role of Grammar Instruction in a Communicative Approach. The Modern Language Journal. 75(1): 52-63. http://dx.doi.org/ 10.1111/j.1540-4781.1989.tb02537.x

[28] Thornbury, Scott. (1999). How to Teach Grammar. Essex: Pearson Education Limited.

[29] Wajnryb, Ruth. (1990). Grammar Dictation. Oxford: Oxford University Press.

[30] Warriner, J. E. "The Teaching of Composition." Pamphlet published by Harcourt School Department, n.d.

[31] Weaver, C. \& C. Mc Nally \& S. Moerman. (2001). To Grammar or Not to Grammar: That is Not the Question. Voices from the $\begin{array}{llllllll}\text { Middle. } & 8(3): & 17-34 & \text { Retrieved } & \text { on } & \text { September } & 14, & 2012\end{array}$ <www.learner.org/workshops/middlewriting/images/.../W8ReadGrammar.pdf>

Çağrı Tuğrul Mart graduated from English Language Teaching Department in 1999 at Selcuk University in Turkey and had his master degree in English Language and Literature in 2010 at Fatih University in Istanbul, Turkey. He is currently working at Ishik University as an instructor in Iraq. His research interests are approaches to language learning. 